\title{
L. T. HOBHOUSE
}

\section{Sociology \& Philosophy}

A Centenary Collection of Essays and Articles, chosen and introduced by Professor Morris Ginsberg, pupil, colleague and friend of Hobhouse, and with a Preface by Sir Sydney Caine, present Director of the L.S.E. The collection presents Hobhouse's leading ideas, many of them relevant to today's problems, in succinct form and is composed of articles very difficult to find these days. 368 pages.

45s. net

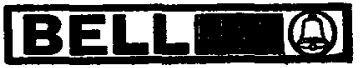

Vol. VIII

\section{JUNE 1966 \\ RATIO}

edited in co-operation with

H. B. Acton (London), P. Bernays (Zïrich), A. Church (Princeton), H. Cherniss (Princeton), G. Henry-Hermann (Bremen), W. C. Ineale (OAford), E. Nagel (Columbia) K. R. Popper (London) and J. W. N. Watkins (London) by Stephan Körner (Bristol)

W. Stremülrer Explanation, prediction, scientific systematization and non-explanatory information

W. Bersswanger Hermann Weyl and Mathematical texts

N. Rescher and J. RoBIsson

J. O. WISDOM

Temporarily Conditioned Descriptions Testing and Psycho-Analytic Interpretation H. Khatchadourian About Imaginary Objects J. KNox

On Mr. Nelson's Rejection of Sense-Data

A. Frew

Did Hume Distinguish Pure from Applied Geometry?

Reviews:

R. Harré: Matter and Method (G. Buchdahl)

M. Warnock: The Philosophy of Sartre (D. Pole)

Price 158. Annual subscription: 27s. 6d, net 


\title{
FOUNDATIONS OF LANGUAGE
}

\author{
International Journal of Language and Philosophy
}

Editorial Board: Morris Halle (MIT), Peter Hartmann (Munster/W), K. Kunjunni Raja (Madras), Benson Mates (Univ. of California), J. F. Staal (Amsterdam), Pieter A. Verburg (Groningen), John W. M. Verhaar (Manila)

\section{VOLUME II - No. 1 - FEBRUARY 1966}

Articles: R. H. Robins: The Development of the Word-Class System of the European Grammatical Tradition-Charles Hartshorne: Some Reflections on Metaphysics and Language- $D$. Terence Langendoen: A Note on the Linguistic Theory of M. Terentius Varro-Charles E. Caton: On the General Structure of the Epistemic Qualification of Things Said in English-J. F. Staal: Analyticity. -Reviews-Publications Received for Review.

FOUNDATIONS OF LANGUAGE is published quarterly Annual subscription price $f 42$. $-(\$ 11.75 ; 84 \mathrm{~s}$.)

D. REIDEL PUBLISHING COMPANY / DORDRECHT-HOLLAND

April 1966

Vol. LXXV. No. 298

\section{MIND}

\section{A QUARTERLY REVIEW OF PSYCHOLOGY AND PHILOSOPHY}

Edited by Prof. GILBERT RYLE

I. Conscious and Unconscious Motives: LEWIS WHITE BECK

II. Rules and Consequences: ANDREW OLDENQUIST

III. Price on Infallibility: BRICE NOEL FLEMING

IV. Ziring Ziderata: FRED I. DRETSKE

V. Responsibility, Freedom, and Punishment: O. C. JENSEN

VI. Discussion Notes:

Promises and Practices: CHARLES LANDESMAN

R. M. Hare's Reformulation of the Open Question: JOHN F. LANGE

Dr. Peter's Motives: J. J. JENKINS

A Note of Wittgenstein's Truth-Function-Generating Operation in Tractatus 6: L. H. HACKSTAFF

Mistake in Performance: LAURENGE D. HOULGATE

VII. Critical Notices:

J. L. Austin, How to do things with words: WALTER GERF

The Philosophy of Rudolf Camap. Edited by P. A. Schilpp: STEPHAN KORNER

VIII. New Books

IX. Notes

Published for the MIND ASSOCtATION by BASIL BLACKWELL, OXFORD 


\section{Revolution in Ethical Theory}

\section{GEORGE C. KERNER}

An introduction to contemporary ethical theory. The author discusses the contributions of Moore, Stevenson, Toulmin, and Hare and subjects their views to a detailed critical analysis, putting the fundamental questions concerning the nature of moral language and reasoning into a clearer light.

$45 s$ net

\section{The Existence of God}

\section{WALLACE I. MATSON}

¿... a useful book ... fulfilling a real need ...' PHILOSOPHICAL Books

'With admirable clearness and economy he marshals the criticisms which analytical philosophers have brought against the familiar "proofs" of God's existence. If any reader wants a book which will show what we are up against in contemporary rationalism, I can think of none better than this...' THEOLOGY 40s net

\section{The}

\section{Philosophy of Hegel}

\section{G. R. G . MURE}

The author summarizes Hegel's mature system, following Hegel's own order of exposition, and prefaces his summary with a brief account of Hegel's early writings. $12 s 6 d$ net

(Home University Library)

\section{$O X F O R D$}

\section{UNIVERSITY}

$P R E S S$

\section{THE PHILOSOPHICAL QUARTERLY}

Contents of Volume 16, No. 63, April 1966

i Wittgenstein's Exclusion of Metaphysical Nonsense Print P. HallIE ii Austin on 'Could' and 'Could Have' iii Practical Reasoning and Values. AYers Nicholas Rescher iv On Being Able to do Otherwise

Clmagert DORr

$\checkmark$ Discusion:

Tensed Discourse and the Eliminability of Tenses Taylor on Pain Location

L. C. Holborow Negative and Positive Duties: A Reply

Bernard Mayo

vi Critical Study

The Structure of Language by J. A. Fodor and J. J. Katz i. JonATHuN CoHEN vii Analytic-Synthetic-A Bibliography

viii Book Reviews ROLAND HaLl.

ix List of Books Received

Edited by G. P. Henderson with the assistance of Roland Hall and published for the Scots Philosophical Club by the University of St Andrews.

Price twenty-five shillings per annum (in U.S.A. \$4.00), post froe, for orders placed directly with the Treasurer (Miss J. S. M Allan, The University, St Andrews, Scotland) or the Assistant Treasurer (Prof. $v$. $C$ Chappell, Department of Philosophy, University of Chicago, Chicago 37, Ilinois, U.S.A.). For orders placed through bookcellers or agents the price is thirty shilling
per annum (in U.S.A. $\mathbf{5 . 0 0}$ ).

\section{THE BRITISH JOURNAL OF AESTHETICS}

A Jourel for the underutanding and apereciation of the arts, and of the pribetiste of criticinen.

Editor: Hanoun Oanonest

Volume 6, No. 2 April 1966

\section{CONTENTS}

Gardens as an Art Form

F. R. Cowel Art and Value

John Brucs

Phenomenology and Concept in Art

Illusion and the Novel IRviNo L. ZUPNICK The Architectural Design Process

Glubert Herabert

Piano Performance Memory IRVin Laszio

The Aesthetics of Luigi Parayson Huoh T. Brebn

BoOR RevEwws

Publlshed Quarterly for the British Society of Aesthetics by Thames \& Hudson, Led, 30 Bloomsbury St. W.C.1. Price 63 per annum (single issues is/6) from the publishers or through any bookseller. The Journal is supplied free to members of the Society: subscription two guineas Der annum. Forms of application from the Hon. Sectetary clo Department of Philosophy, Bedford Colleze, Regenr's Park. London, N.W.1. 


\section{MAN, THE UNIVERSE AND MIND}

\section{An Essaylin Empirical Analysis}

by P. A. Moritz

“... demonstrates the origination of metaphysical issues in experiential phenomena, in opposition to the contemporary linguistic confusion theory."

". . . high-lights the true role of everyday thinking and of ordinary language usage, in the complex world of today."

102 pages

8/6d.

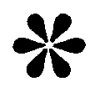

\section{MARTIGAN PUBLICATIONS}

Nethercot Mill . Combe Florey . Taunton . Somerset . England

\section{Christian Ethics and Contemporary Philosophy}

edited by Ian T. Ramsey

Not only are the most diverse people now critical of underpinning morality by theolosymany are puszled about the whole character of Christian ethics.', The esenyints in this volume include unbelievers, Fagnontics, Yand Chriatians who are assorted and mostly lay. Most of their 24 easays are gathered from recent numbers of philosophical journaly, but eight were written specially for this book. They are united by a concern about this new situation, and by a wish to reason reliably about it.

\section{0 pp. 50 s net}

SCM PRESS

\section{Book Collections} and Libraries

\section{Purchased}

IN THE ARTS \& HUMANITIES

\section{Especially}

PHILOSOPHERS \&

PHILOSOPhy (All Periods)

RELIGIONS MORALS ETHICS

Philosophical Periodicals STANDARD SETS

\section{STANLEY NOBLE,}

University Bookseller,

24 Gladwell Road, London, N.8 MOUntview 2831

We are prepared to travel ANY distance if to our MUTUAL advantage 


\section{Polarity and Analogy}

Two Types of Argumentation in Early Greek Thought

G. E. R. LLOYD

A study of the two types of argument used in Greek thought from Thales to Aristotle:-Polarity, the doctrine of opposites and Analogy, the doctrine of similarities.

84s. net

\section{Plato's Thought in the Making}

\section{J. E. RAVEN}

A detailed study in English of all the passages in the Platonic dialogues which relate to Plato's central Theory of Ideas. 'The book is superbly well written and immensely readable and it can be recommended as an ideal introduction to Plato both for the general reader and for the classical student.' Times Literary Supplement.

Cloth, 27s. 6d. net; Paperback, 12s. 6d. net

\section{CAMBRIDGE UNIVERSITY PRESS}

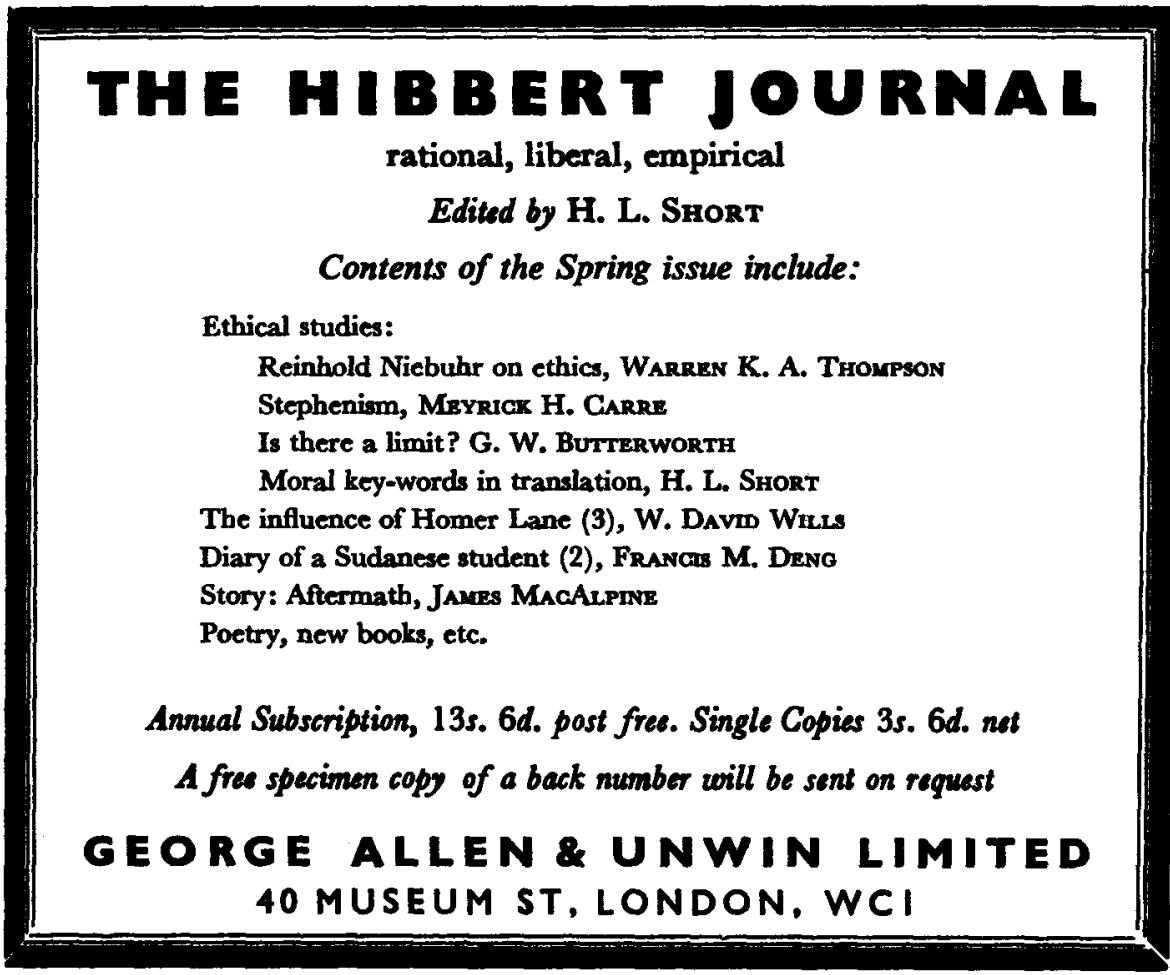




\section{ER Emmet}

IEARNING TO THINK

Designed for use in the classrooms of senior forms in secondary schools, this book shows how thinking works. It demonstrates the principles of valid reasoning and aims, above all, to sharpen wits and critical faculties. A separate volume, COMPANION TO LEARNING TO THINK (6s.) provides full comments and where applicable, worked out solutions to the exercises.

\section{LEARNING TO PHILOSOPHISE}

The author is concerned with the activity of philosophising rather than with the subject of philosophy. The book will be of great interest and value to sixth form students and first year undergraduates.

\section{THE USE OF REASON}

A direct study of the processes of thinking. The book explains the workings of formal logic, and stresses the importance of flexibility in thinking. 